American Journal of Agricultural and Biological Sciences 5 (3): 274-281, 2010

ISSN 1557-4989

(C) 2010 Science Publications

\title{
Effect of Municipal Solid Waste Compost on the Growth and Production of Vegetable Crops
}

\author{
${ }^{1}$ A.E. Ghaly and ${ }^{2}$ F.N. Alkoaik \\ Department of Process Engineering and Applied Science, Faculty of Engineering, \\ Dalhousie University, Halifax, Nova Scotia, Canada \\ Department of Agricultural Engineering, College of Agriculture and Food Sciences, \\ King Saud University, Riyadh, Kingdom of Saudi Arabia
}

\begin{abstract}
Problem statement: MSW has traditionally been dealt with thorough the practice of land filling and incineration. However, deleterious environmental impacts have promoted municipalities in Canada to recycle non-putrescible wastes and compost the putrescible ones. This study aimed at evaluating the effect of MSW compost on the growth and production of three vegetable crops (potatoes, corn and squash). Approach: Each crop received 5 treatments: $\mathrm{MSW}_{1}, \mathrm{MSW}_{2}, \mathrm{MSW}_{3}, \mathrm{NPK}$ and $0.5 \mathrm{NPK}, 0.5 \mathrm{MSW}_{1}$. MSW 2 and $\mathrm{MSW}_{3}$ were twice and three times $\mathrm{MSW}_{1}$, respectively. $\mathrm{MSW}_{1}$ was determined for corn and potato based on phosphorous requirements by these crops and the phosphorous content of the MSW compost and was determined for squash based on the nitrogen requirement by the plant and the nitrogen content of the MSW compost. The choice of chemical fertilizer and application rate were based on the optimum NPK ratio for each plant. Samples from the plants were taken at specific growth stages and at harvest for visual health and dry matter analyses. Results: The plant yield for each crop followed the same patterns as those of the visual observations for health ranking and the dry matter. The results showed that $0.5 \mathrm{NPK}+0.5 \mathrm{MSW}_{1}$ gave the best plant growth, health and yield for potato and corn while NPK gave the best plant growth, heath and yield for squash. Squash did not seem to respond well to MSW compost. Conclusion: The plots that received $\mathrm{MSW}_{2}$ were healthier than those reserved $\mathrm{MSW}_{1}$ and $\mathrm{MSW}_{3}$. High rate of MSW may provide higher level of heavy metals than the plant can tolerate while low rate of MSW may not contain all the other required micro-nutrients. Long tern effects of MSW compost on the chemical and microbiological properties of the soil and the plant properties such as taste, appearance, storability, susceptibility to bugs and disease should be evaluated.
\end{abstract}

Key words: MSW, compost, growth, yield, potato, sweet corn, squash, heavy metal

\section{INTRODUCTION}

Municipal Solid Waste (MSW) constitutes that portion of solid waste stream originating from households, institutions, commercial and service establishments, offices and public facilities and construction and demolition sites. A typical composition of municipal solid waste is shown in Fig. 1 (NSDOE, 1995). Canadians produce more solid waste per capita than most industrial countries. Over 23 million tons of solid wastes are generated in Canada each year, one third of which originate from residential sources (Statistics Canada, 2002). MSW production in developing countries such as Canada is substantially more than MSW produced from less developed countries. This is in part due to the accumulation of material goods in developed countries and the resourcefulness associated with the recovery and reuse of material in less developed regions of the world (Maso and Blasi, 2008).

The MSW stream is divided into two categories putrescible (organic) fraction and non-putrescible fraction. The non-putrescibles do not readily decompose and are represented in the waste stream by glass, metals, textiles, plastics, un-soiled paper products and stones. Putrescibles decompose more readily and are represented in the waste stream by yard and kitchen wastes, soiled paper products and to lesser degree wood. In Halifax Regional Municipality, the largest in the Province of Nova Scotia, the putrescible fraction constitutes approximately $41 \%$ of the MSW stream or $259 \mathrm{~kg} /$ capita-year (NSDOE, 1995).

Corresponding Author: A.E. Ghaly, Department of Process Engineering and Applied Science, Faculty of Engineering, Dalhousie University, Halifax, Nova Scotia, Canada Tel: (902)494-6014 


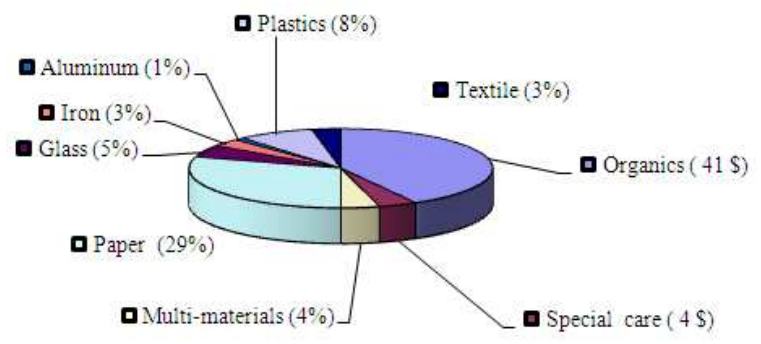

Fig. 1: Solid waste composition (NSDOE, 1995)

MSW has traditionally been dealt with thorough the practices of land filling and incineration. However, deleterious environmental impacts have promoted municipalities in Canada to recycle certain nonputrescible wastes and compost the putrescible fraction. In 1989, the Province of Nova Scotia, in step with the Canada Council of Ministers of the Environment (CCME), sat a solid waste diversion goal of $50 \%$ by 2000 (NSDOE, 1995). The goal was formally adopted in the Environmental Act of the Province and the target was achieved on time resulting in a diversion of 650000 tons from landfills.

Diverting the organic portion of the waste stream from landfills minimizes the pollution potential of the residential waste and reduces the quantity of the remaining waste product by $40-60 \%$. Treating the biodegradable fraction as a feed stock for a controlled decomposition process (composting) stabilizes the putrescible organics quickly and produces a soil amendment that can improve soil fertility, texture and water holding capacity.

Since 1989, fifteen composting systems were funded and built in Nova Scotia to cater to the diversion program. However, the issue of how to utilize the compost has never been addressed till now. Several studies (Ko et al., 2008; Gomez-Brandon et al., 2008; Wang et al., 2004; Paion, 1996; Ozores-Hampton, 1994; Maynard, 1993; Havard and Warman, 1993; Jimenez and Garcia, 1992; Mays, 1973) have shown that the compost products are rich in plant nutrients and organic matter which can improve plant growth. Mays (1973) showed a positive yield response to compost application in sorghum, Bermuda grass and corn and improved soil moisture holding capacity but also concerns were raised due to presence of foreign materials that could be ingested by animals over pasture land or in hay. Roe (1993) reported a higher zinc concentration in soil and a low germination rate of squash after application of MSW compost. Maynard (1995) reported 58\% higher yield in tomato crop amended with $11.2 \mathrm{t} \mathrm{ha}^{-1}$ MSW compost but noticed symptoms of damping off diseases and dying in squash. Ozores-Hampton (1994) reported improved tomato growth and yield after applying MSW compost but questioned the high cost compared to commercial fertilizer. Paion (1996) reported significant increase in corn growth and yield but noticed proportional increase in copper and zinc. Compost materials are largely used by the landscape industry due to the presence of heavy metals (Roe, 1993). Consumers are, therefore, concerned about the physical impurities (glass and plastics) as well as the presence of heavy metals.

The aim of this study was to evaluate the effect of MSW compost on the performance of vegetable crops. The specific objectives were: (a) to determine the amount of MSW compost required based on the nutrient availability in compost and the nutrient requirement by the plants, (b) to determine the effect of various application rates of MSW compost on three vegetable crops (potato, sweet corn and squash) as measured by dry matter, yield and the visual health of the plant and (c) to compare the results obtained with the application of MSW compost with those obtained with the application of commercial fertilizer

\section{MATERIALS AND METHODS}

MSW compost: The compost used in this study originated from Miller Composting Corporation, Dartmouth, Nova Scotia. The organic material composted at this plant included boxboard, small tree brunches and trimmings, cheese and dairy products, egg cartons, fats and greases, grass clippings, food wastes, meat, fish, bones, napkins, paper towels, tea bags, coffee filter, leaves and vegetable scrap. After the organic materials are properly inspected, separated and shredded, it is put into a plug flow composting system, equipped with aeration and mixing units. Once the initial composting process is completed, the material is transformed into a curing pad and allowed further degradation for several months. The compost product used in this study was free of odor, but it did contain a small amount of foreign materials as defined by the CCME (2000). Some characteristics of the compost used in the study are shown in Table 1. This compost would not be accepted as grade A as defined by the CCMW based on the $\mathrm{Cu}$ content.

Mineral fertilizers: Three types of chemical fertilizers were used: $\mathrm{NO}_{3}(34-0-0), \mathrm{P}_{2} \mathrm{O}_{5}(0-46-0)$ and $\mathrm{K}_{2} \mathrm{O}$ (0-0-60). They were used according to the crop demand and the present soil fertility level. These fertilizers were obtained from a local supplier in Truro, Nova Scotia. 
Am. J. Agri. \& Biol. Sci., 5 (3): 274-281, 2010

Table 1: Some characteristics of the municipal solid waste compost

\begin{tabular}{lr}
\hline Characteristics & Measured value \\
\hline Moisture content $(\%)$ & 59.0 \\
Total volatile solids (mg g-1 DM) & 854.0 \\
Total fixed solids $\left(\mathrm{mg} \mathrm{g}^{-1} \mathrm{DM}\right)$ & 146.0 \\
Total kjeldah nitrogen $\left(\mathrm{mg} \mathrm{g}^{-1} \mathrm{DM}\right)$ & 18.0 \\
Ammonium nitrogen $\left(\mathrm{mg} \mathrm{g}^{-1} \mathrm{DM}\right)$ & 5.0 \\
Total carbon $\left(\mathrm{mg} \mathrm{g}^{-1} \mathrm{DM}\right)$ & 440.0 \\
Elemental composition $\left(\mathrm{mg} \mathrm{g}^{-1} \mathrm{DM}\right)$ & \\
$\mathrm{Ca}$ & 20.0 \\
$\mathrm{Na}$ & 6.2 \\
$\mathrm{Fe}$ & 14.6 \\
$\mathrm{Mg}$ & 2.8 \\
$\mathrm{Zn}$ & 1.1 \\
$\mathrm{~K}$ & 7.8 \\
$\mathrm{Cl}$ & 3.2 \\
$\mathrm{P}$ & 2.9 \\
$\mathrm{~S}$ & 2.5 \\
$\mathrm{Mn}$ & 1.1 \\
$\mathrm{Cu}$ & 211.0 \\
Electrical conductivity (Mmhos) & 0.7 \\
$\mathrm{C}: \mathrm{N}$ & $24: 1$ \\
$\mathrm{pH}$ & 7.3 \\
\hline
\end{tabular}

\begin{tabular}{|c|c|c|c|c|c|}
\hline \multirow{4}{*}{$\left(\mathrm{MSW}_{1}\right)_{\mathrm{p}}$} & $\mathrm{R}_{1}$ & \multirow{4}{*}{$\left(\mathrm{MSW}_{1}\right)_{\mathrm{K}}$} & $\mathrm{R}_{1}$ & \multirow{4}{*}{$\left(\mathrm{MSW}_{1}\right)_{\mathrm{s}}$} & $\mathrm{R}_{1}$ \\
\hline & $\mathrm{R}_{2}$ & & $\mathrm{R}_{2}$ & & $\mathrm{R}_{2}$ \\
\hline & $R_{3}$ & & $\mathrm{R}_{3}$ & & $\mathrm{R}_{3}$ \\
\hline & $R_{4}$ & & $\mathrm{R}_{4}$ & & $\mathrm{R}_{4}$ \\
\hline \multirow{4}{*}{$\left(M_{S W}\right)_{P}$} & $R_{1}$ & \multirow{4}{*}{$\left(\mathrm{MSW}_{2}\right)=$} & $\mathrm{R}_{1}$ & \multirow{4}{*}{$\left(\mathrm{MSW}_{2}\right)_{\mathrm{s}}$} & $\mathrm{R}_{1}$ \\
\hline & $\mathrm{R}_{2}$ & & $\mathrm{R}_{2}$ & & $\mathrm{R}_{2}$ \\
\hline & $R_{3}$ & & $\mathrm{R}_{3}$ & & $\mathrm{R}_{3}$ \\
\hline & $R_{4}$ & & $\mathrm{R}_{4}$ & & $\mathrm{R}_{4}$ \\
\hline \multirow{4}{*}{$\left(\mathrm{MSW}_{3}\right)_{2}$} & $\mathrm{R}_{1}$ & \multirow{4}{*}{$\left(\mathrm{MSW}_{3}\right)_{0}$} & $\mathrm{R}_{1}$ & \multirow{4}{*}{$\left(\mathrm{MSW}_{3}\right)_{5}$} & $\mathrm{R}_{1}$ \\
\hline & $\mathrm{R}_{2}$ & & $\mathrm{R}_{2}$ & & $\mathrm{R}_{2}$ \\
\hline & $\mathrm{R}_{3}$ & & $\mathrm{R}_{3}$ & & $\mathrm{R}_{3}$ \\
\hline & $\mathrm{R}_{4}$ & & $\mathrm{R}_{4}$ & & $\mathrm{R}_{4}$ \\
\hline \multirow{4}{*}{$(\mathrm{NPK}) \mathrm{p}$} & $\mathrm{R}_{1}$ & \multirow{4}{*}{$(\mathrm{NPK})=$} & $\mathrm{R}_{1}$ & \multirow{4}{*}{$(\mathrm{NPK})_{s}$} & $\mathrm{R}_{1}$ \\
\hline & $\mathrm{R}_{2}$ & & $\mathrm{R}_{2}$ & & $\mathrm{R}_{2}$ \\
\hline & $R_{3}$ & & $\mathrm{R}_{3}$ & & $\mathrm{R}_{3}$ \\
\hline & $R_{4}$ & & $R_{4}$ & & $\mathrm{R}_{4}$ \\
\hline \multirow{4}{*}{$\left(\mathrm{NPK}+0.5 \mathrm{MSW}_{1}\right)_{\mathrm{p}}$} & $\mathrm{R}_{1}$ & \multirow{4}{*}{$\left(\mathrm{NPK}+0.5 \mathrm{MSW}_{1}\right)$} & $\mathrm{R}_{1}$ & \multirow{4}{*}{$\left(\mathrm{NPK}+0.5 \mathrm{MSW}_{1}\right)_{\mathrm{s}}$} & $\mathrm{R}_{1}$ \\
\hline & $\mathrm{R}_{2}$ & & $\mathrm{R}_{2}$ & & $\mathrm{R}_{2}$ \\
\hline & $R_{3}$ & & $\mathrm{R}_{3}$ & & $R_{3}$ \\
\hline & $\mathrm{R}_{4}$ & & $R_{4}$ & & $R_{4}$ \\
\hline Block 1 & & & & & Block \\
\hline
\end{tabular}

Block $=320 \mathrm{~m}^{2}$

Plot $=64 \mathrm{~m}^{2}$

Subplot $(2 \mathrm{R})=16 \mathrm{~m}^{2}$

$\mathrm{P}=$ Potato

$\mathrm{C}=$ Corn

$\mathrm{C}=$ Corn
$\mathrm{S}=$ Squash

Fig. 2: Experimental layout

Agricultural chemicals: Several agricultural chemical were use in this study for weed, insect and disease control. Roundup, Atrazine (Aatrex-Nine-O) and Metribuzin (Lextone) were use for weed control. Permethrin (Ambush), Carbytyl (Seven) and Admine were use for controlling potato blight. All chemicals were obtained from a local supplier in Truro, Nova Scotia.

Plot layout: The three vegetable crops were planted at commercial farm in Truro, Nova Scotia about $100 \mathrm{~km}$ from Halifax. The soil was sandy loam and contained low organic matter. The field remained free of crops in the previous year. A randomized complete block design was used. Each crop was planted in a $320 \mathrm{~m}^{2}$ block $(16 \times 20 \mathrm{~m})$. Five different applications rates were used: $\mathrm{MSW}_{1}, \mathrm{MSW}_{2}, \mathrm{MSW}_{3}, \mathrm{NPK}$ and $1 / 2 \mathrm{NPK}+1 / 2 \mathrm{MSW}_{1}$. Each block was divided into 5 plots, each was $64 \mathrm{~m}^{2}$. Four replicates were used in each plot (resulting in 4 sub-plots of $16 \mathrm{~m}^{2}$ each). This meant that $20 \mathrm{sub}$-plots were used for each crop. The Experimental layout is shown in Fig. 2.

Fertilizer application: The application rates of lime, chemical fertilizer and compost are shown in Table 2. Lime was applied to the squash plots as the squash require an optimum soil $\mathrm{pH}$ higher than that required by the other two crops. The $\mathrm{MSW}_{1}$ application rate was determined for corn and potato based on phosphorus requirements by these two crops and the phosphorus content of the MSW compost (assuming 100\% availability). The $\mathrm{MSW}_{1}$ application rate for squash was based on the nitrogen requirement by the plant and the nitrogen content of the MSW compost (assuming 50\% availability). $\mathrm{MSW}_{2}$ and $\mathrm{MSW}_{3}$ were twice and three times of $\mathrm{MSW}_{1}$, respectively. The Choice of chemical fertilizer and application rates were determined base on the optimum NPK rate for each plant.

Field preparation: The three fields were treated with Roundup 10 days before initial tilling for weed control. The field was then tilled twice at a depth of $25 \mathrm{~cm}$. Once each plot received the assigned amount of MSW compost and fertilizer (and lime), the field was tilled to incorporate the compost and fertilizer into the top $15 \mathrm{~cm}$ of the soil.

Planting: The corn was planted on May 16 in small furrows. The seeds were planted $15 \mathrm{~cm}$ apart and the rows were $90 \mathrm{~cm}$ apart. This amounted to 19 seeds/row and 76 seeds/ plot. On June 1, additional seeds were planted in the spots where plants did not emerge.

The potatoes were planted on May 16 in larger furrows approximately $15 \mathrm{~cm}$ deep. The seeds were planted $30 \mathrm{~cm}$ apart and the rows were $90 \mathrm{~cm}$ apart. This amounted to 10 seeds/row and 40 seeds/plot. 
Am. J. Agri. \& Biol. Sci., 5 (3): 274-281, 2010

Table 2: Application rates

\begin{tabular}{|c|c|c|c|c|c|c|c|}
\hline \multirow[b]{2}{*}{ Crop } & \multicolumn{2}{|c|}{ MSW compost } & \multicolumn{3}{|l|}{ NPK fertilizer } & \multicolumn{2}{|l|}{ Lime } \\
\hline & $\left(\mathrm{t} \mathrm{h}^{-1}\right)$ & $\left(\mathrm{Kg} \mathrm{plot}^{-1}\right)$ & (Type) & $\left(\mathrm{Kg} \mathrm{h}^{-1}\right)$ & $\left(\mathrm{g} \mathrm{plot}^{-1}\right)$ & $\left(\mathrm{t} \mathrm{h}^{-1}\right)$ & $\left(\mathrm{g} \mathrm{plot}^{-1}\right)$ \\
\hline \multirow[t]{3}{*}{ Corn } & 7.5 & 12.0 & $\mathrm{NO}_{3}(34-0-0)$ & 135 & 635 & & \\
\hline & 15.0 & 24.0 & $\mathrm{P}_{2} \mathrm{O}_{5}(0-46-0)$ & 050 & 174 & & \\
\hline & 22.5 & 36.0 & $\mathrm{~K}_{2} \mathrm{O}(0-0-60)$ & 000 & 000 & & \\
\hline \multirow[t]{3}{*}{ Potato } & 21.7 & 34.7 & $\mathrm{NO}_{3}(34-0-0)$ & 130 & 062 & & \\
\hline & 43.4 & 69.4 & $\mathrm{P}_{2} \mathrm{O}_{5}(0-46-0)$ & 145 & 504 & & \\
\hline & 65.1 & 104.1 & $\mathrm{~K}_{2} \mathrm{O}(0-0-60)$ & 080 & 213 & & \\
\hline \multirow[t]{3}{*}{ Squash } & 24.0 & 38.4 & $\mathrm{NO}_{3}(34-0-0)$ & 120 & 565 & 1.6 & 51.2 \\
\hline & 48.0 & 76.8 & $\mathrm{P}_{2} \mathrm{O}_{5}(0-46-0)$ & 200 & 696 & 1.6 & 51.2 \\
\hline & 72.0 & 115.2 & $\mathrm{~K}_{2} \mathrm{O}(0-0-60)$ & 060 & 160 & 1.6 & 51.2 \\
\hline
\end{tabular}

Table 3: Maintenance schedule

\begin{tabular}{|c|c|c|}
\hline Month & Day & Task performed \\
\hline \multirow[t]{3}{*}{ May } & 8 & Sprayed MSW plots with roundup \\
\hline & 9 & Limed squash field and sprayed MSW plots with roundup \\
\hline & 23 & Sprayed potato plots with Lexone and corn plots with Atrazine \\
\hline \multirow[t]{2}{*}{ June } & 18 & Sprayed corn with Ambush at a rate $240 \mathrm{~mL} \mathrm{ha}^{-1}$ \\
\hline & 18 & Hilled potato rows \\
\hline \multirow[t]{6}{*}{ July } & 8 & Sprayed potatoes with seven at a rate of $3 \mathrm{~kg} \mathrm{ha}^{-1}$ \\
\hline & 8 & Hilled potato rows \\
\hline & 12 & Sprayed potatoes with Admine at a rate of $150 \mathrm{~mL} \mathrm{ha}^{-1}$ \\
\hline & 17 & Sprayed potatoes with Bravo at rate of $2 \mathrm{~L} \mathrm{ha}^{-1}$ \\
\hline & 26 & Sprayed potatoes with Bravo at rate of $2 \mathrm{~L} \mathrm{ha}^{-1}$ \\
\hline & 26 & Sprayed corn with Admine at a rate of $240 \mathrm{~mL} \mathrm{ha}^{-1}$ \\
\hline
\end{tabular}

The squash was initially planted in $125 \mathrm{~mm}$ diameter fibre pots containing a mixed soil (soil: Peat: Nutritional Mix at 2:1:1). The pots were kept in growth chamber for three weeks (from May 16 until June 6) on a cycle of $16 \mathrm{~h}$ of light and $8 \mathrm{~h}$ of darkness. The pots were watered daily and the temperature was maintained at $20^{\circ} \mathrm{C}$. The plants were transplanted in the field on June 6 and were spaced two meters apart. The rows were designed to allow one meter distance between each plant within the plot. There were 24 plants/plot.

Maintenance: The maintenance schedule of the different crops was organized according to the Vegetable Production Recommendations of the Province of Ontario (OMOA, 1982) as presented in Table 3. The corn was sprayed with Permethrin (Ambush) for insect control and Atrazine (Aatrex-NineO) for early weed control. The potatoes were sprayed with Carbyty1 (Seven) and Admine for insect control and with Metribuzin (Lexone) at the beginning of the season for weed control. In addition, Chlorothalonil (Bravo $500 \mathrm{~F}$ ) was used for blight control. Also, twice during the growing season (June 18 and July 8), the potato furrows were hilled in order to prevent sunburn to the tubers. The squash was routinely weeded wherever thought necessary. Also, because of initial dry condition, the squash plants were watered when necessary.
Visual observation: A visual health observation ranking system was developed to describe the growth and health of the plants. A scale of 1-10 was used where 1 is the lowest and 10 is the highest. The ranking system was based on colour, size, insect damage and signs of toxicity.

Sampling: Samples were taken from the plants at specific growth stages and at harvest. When the corn plant exhibited ear development, random samples were taken from each plot. The whole corn plant was sampled on August 4 and the above ground biomass was separated from the roots. Two plants per row (eight per plot) were randomly selected for sampling. At harvest, the corn ears were collected and weighed.

The potatoes were sampled shortly after flowering. The whole potato plant was sampled on July 31 and the above ground biomass was separate from the roots and tubers. Two plants per row (eight per plot) were randomly selected for sampling. The potato tubers were collected and weighed.

The most recent developed leaf was sampled from the squash plants. The whole squash plant was sampled on August 29 after most plants produced fruit and the above ground biomass was separated from the roots. Two plants per row (eight plants) were randomly selected for sampling. The squash fruit were collected and weighed. 
Moisture content measurement: Moisture content was performed using dry oven method following the procedure described in APHA (1990). Samples were weighed using a Mettler Scientific Scale (AE 200s, Mettler Instrument AG. Greifensee-Zurich, Switzerland). The weigh was recorded to the nearest $0.0001 \mathrm{~g}$. Wet sample was oven dried at $105^{\circ} \mathrm{C}$ for $24 \mathrm{~h}$ in an air forced drying oven (Isotemp Oven, Model No. 655F, Fisher Scientific, Toronto, Ontario, Canada). The moisture content was then determined using the following formula:

$$
M_{c}=\frac{W W-D W}{W W} \times 100
$$

Where:

$\mathrm{M}_{\mathrm{c}}=$ Moisture content in percent (\%)

$\mathrm{WW}=$ Wet Weight $(\mathrm{g})$

DW $=$ Dry Weight $(\mathrm{g})$

pH measurement: The $\mathrm{pH}$ was measured using Fisher Accumet pH meter (Model 805 MP, Fisher Scientific, Pittsburgh, PA, USA). A $50 \mathrm{~g}$ sample of the soil was diluted (1:10) with distilled, de-ionized water and placed in a mechanical shaker at $230 \mathrm{rpm}$ for $30 \mathrm{~min}$ prior to $\mathrm{pH}$ measurement.

\section{RESULTS}

Plant growth: The effects of the various treatments on growth performance of the plants as measured by the dry matter and visual health observation are shown in Table 4-6. The quantitative and qualitative measurements for the corn plants taken on August 4, shortly after the ears had matured, are presented in Fig. 2. The quantitative and qualitative measurements for potato, taken shortly following blossoming, are presented in Fig. 3. The quantitative and qualitative measurements for the squash plants taken after fruiting are presented in Fig. 4.

Plant production: The average number of corn ears per plot and the average height of the corn plant are shown in Table 7. The average number of potatoes per plot and the average volume of potato plant canopy are shown in Table 8 . The average number of fruits and the average volume of squash plat canopy are presented in Table 9 .

Table 4: Growth performance of corn

\begin{tabular}{|c|c|c|c|}
\hline \multirow[b]{2}{*}{ Treatment } & \multicolumn{3}{|c|}{ Average weight of 8 plants } \\
\hline & $\begin{array}{l}\text { Above ground } \\
\text { dry mater }(\mathrm{g})\end{array}$ & $\begin{array}{l}\text { Dry root } \\
(\mathrm{g})\end{array}$ & $\begin{array}{l}\text { Visual health } \\
\text { ranking* }\end{array}$ \\
\hline $\mathrm{MSW}_{1}$ & 394 & 38 & 9.0 \\
\hline $\mathrm{MSW}_{2}$ & 395 & 39 & 9.0 \\
\hline $\mathrm{MSW}_{3}$ & 348 & 34 & 8.0 \\
\hline NPK & 351 & 33 & 7.8 \\
\hline $0.5 \mathrm{NPK}+0.5 \mathrm{MSW}_{1}$ & 450 & 43 & 9.8 \\
\hline
\end{tabular}

Table 5: Growth performance of potatoes

\begin{tabular}{llll}
\hline & Average weight of 8 plants & \\
\cline { 2 - 4 } & $\begin{array}{l}\text { Above ground } \\
\text { dry mater }(\mathrm{g})\end{array}$ & $\begin{array}{l}\text { Dry root } \\
(\mathrm{g})\end{array}$ & $\begin{array}{l}\text { Visual health } \\
\text { ranking* }\end{array}$ \\
\hline $\mathrm{MSW}_{1}$ & 204 & 23 & 7.0 \\
$\mathrm{MSW}_{2}$ & 231 & 25 & 7.2 \\
$\mathrm{MSW}^{3}$ & 176 & 20 & 6.2 \\
$\mathrm{NPK}$ & 300 & 28 & 8.2 \\
$0.5 \mathrm{NPK}+0.5 \mathrm{MSW}_{1}$ & 426 & 32 & 9.8 \\
\hline
\end{tabular}

*: Scale of 1-10 was used: 1 is the lowest and 10 is the highest based on colour, size, height, disease, insect damage and sign of toxicity

Table 6: Growth performance of squash

\begin{tabular}{|c|c|c|c|}
\hline \multirow[b]{2}{*}{ Treatment } & \multicolumn{3}{|c|}{ Average weight of 8 plants } \\
\hline & $\begin{array}{l}\text { Above ground } \\
\text { dry mater }(\mathrm{g})\end{array}$ & $\begin{array}{l}\text { Dry root } \\
(\mathrm{g})\end{array}$ & $\begin{array}{l}\text { Visual health } \\
\text { ranking* }\end{array}$ \\
\hline$\overline{\mathrm{MSW}}_{1}$ & 162 & 18 & 4.8 \\
\hline $\mathrm{MSW}_{2}$ & 156 & 16 & 4.6 \\
\hline $\mathrm{MSW}_{3}$ & 149 & 14 & 4.3 \\
\hline NPK & 256 & 36 & 8.8 \\
\hline $0.5 \mathrm{NPK}+0.5 \mathrm{MSW}_{1}$ & 230 & 30 & 7.1 \\
\hline
\end{tabular}

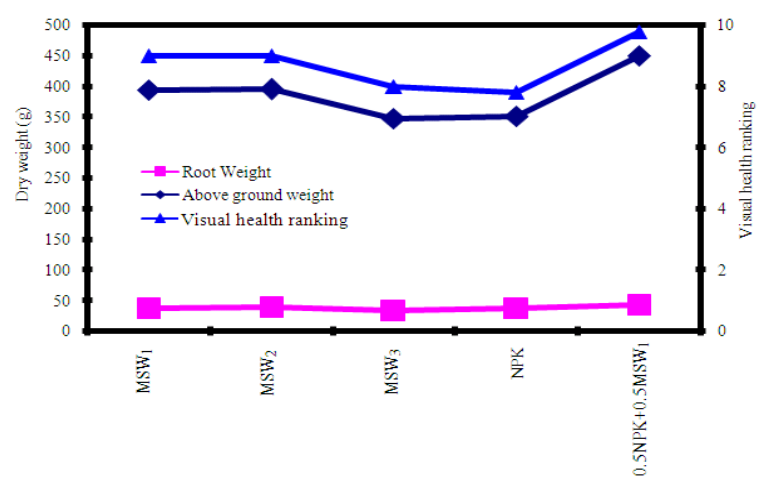

Fig. 3: Effect of treatment on visual health ranking and dry mater of corn plants

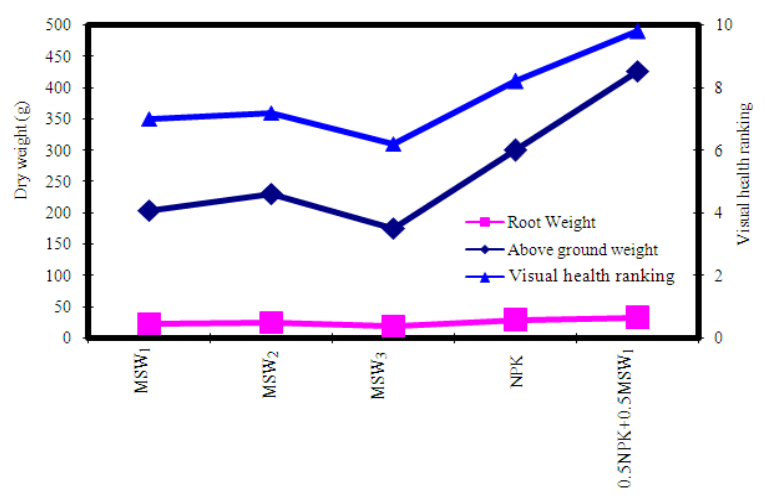

Fig. 4: Effect of treatment on visual health ranking and dry mater of potato plants 


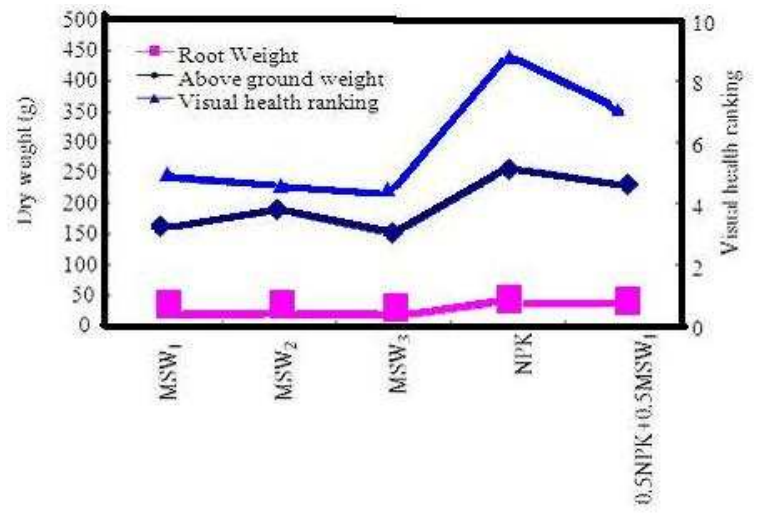

Fig. 5: Effect of treatment on visual health ranking and dry mater of squash

Table 7: Average Number of corn ears and height of plant

\begin{tabular}{|c|c|c|c|c|}
\hline \multirow[b]{2}{*}{ Treatment } & \multicolumn{3}{|c|}{ Average number of ears/plot } & \multirow{2}{*}{$\begin{array}{l}\text { Plant height } \\
(\mathrm{cm})\end{array}$} \\
\hline & Class 1 & Class 2 & Total & \\
\hline $\mathrm{MSW}_{1}$ & 6 & 6 & 12 & 198 \\
\hline $\mathrm{MSW}_{2}$ & 6 & 7 & 13 & 198 \\
\hline $\mathrm{MSW}_{3}$ & 6 & 5 & 11 & 169 \\
\hline NPK & 5 & 6 & 11 & 206 \\
\hline $0.5 \mathrm{NPK}+0.5 \mathrm{MSW}_{1}$ & 6 & 12 & 18 & 212 \\
\hline
\end{tabular}

Class 1: Ear size less than $15 \mathrm{~cm}$; Class 2: Ear size larger than $15 \mathrm{~cm}$

Table 8: Average number of potato produced and size of canopy

\begin{tabular}{|c|c|c|c|c|c|}
\hline \multirow[b]{2}{*}{ Treatment } & \multicolumn{4}{|c|}{ Average number of potatoes/plot } & \multirow{2}{*}{$\begin{array}{l}\text { Average } \\
\text { canopy } \\
\text { volume }\left(\mathrm{m}^{3}\right)\end{array}$} \\
\hline & Class 1 & Class 2 & Class 3 & Total & \\
\hline$\overline{\mathrm{MSW}_{1}}$ & 18 & 18 & 12 & 48 & 0.28 \\
\hline $\mathrm{MSW}_{2}$ & 18 & 20 & 14 & 52 & 0.30 \\
\hline $\mathrm{MSW}_{3}$ & 17 & 16 & 10 & 43 & 0.26 \\
\hline NPK & 21 & 19 & 16 & 56 & 0.44 \\
\hline $0.5 \mathrm{NPK}+0.5 \mathrm{MSW}_{1}$ & 22 & 24 & 20 & 66 & 0.59 \\
\hline
\end{tabular}

Class 1: Potato size less than $100 \mathrm{~g}$; Class 2: Potato size 100-200 g; Class 3: Potato size greater than $200 \mathrm{~g}$

Table 9: Average number of squash produced and size of canopy

\begin{tabular}{lcllll}
\hline \multirow{2}{*}{ Treatment } & \multicolumn{2}{c}{ Average number of fruit/ plot } & $\begin{array}{l}\text { Average } \\
\text { canopy }\end{array}$ \\
& Class 1 & Class 2 & Class 3 & Total & volume $\left(\mathrm{m}^{3}\right)$ \\
\hline $\mathrm{MSW}_{1}$ & 6 & 4 & 0 & 10 & 0.33 \\
$\mathrm{MSW}_{2}$ & 6 & 3 & 0 & 9 & 0.32 \\
$\mathrm{MSW}_{3}$ & 6 & 2 & 0 & 8 & 0.30 \\
$\mathrm{NPK}$ & 10 & 7 & 2 & 19 & 1.11 \\
$0.5 \mathrm{NPK}+0.5 \mathrm{MSW}_{1}$ & 9 & 6 & 0 & 15 & 0.69
\end{tabular}

Class 1: Fruit size less than $5 \mathrm{~cm}$ diameter; Class 2: Fruit size 5-10 $\mathrm{cm}$ diameter; Class 3: Fruit size greater than $15 \mathrm{~cm}$ diameter; Canopy size was calculated from length and width of plants

\section{DISCUSSION}

Plant growth: During the growing season, it was possible to recognize distinct differences between the different treatments in all three crops.
The corn exhibited the least difference among the treatments. The plants matured at a comparable rate. However, the ears in the plots that received commercial fertilizer matured sooner. The quantitative and qualitative measurements for the corn plants taken shortly after the ears had matured showed significant differences in the dry matter and the visual health ranking among the treatments $\operatorname{MSW}_{1}\left(7.5 \mathrm{t} \mathrm{h}^{-1}\right)$ and $\operatorname{MSW}_{2}\left(15 \mathrm{t} \mathrm{h}^{-1}\right)$. However, increasing the compost application rate to $22.5 \mathrm{t} \mathrm{h}^{-1}\left(\mathrm{MSW}_{3}\right)$, decreased both dry matter and the visual health ranking. Applying commercial fertilizer alone (NPK) resulted in better visual heath ranking and higher dry matter than applying $\mathrm{MSW}_{3}\left(22.5 \mathrm{th}^{-1}\right)$ but worse than applying $\operatorname{MSW}_{1}\left(7.5 \mathrm{t} \mathrm{h}^{-1}\right)$ and $\mathrm{MSW}_{2}(15.0 \mathrm{t} / \mathrm{h})$. The best fertilizer treatment for corn was $0.5 \mathrm{NPK}+0.5 \mathrm{MSW}_{1}$ which achieved the highest ranking in visual heath and the greatest dry matter.

The potatoes treated with conventional fertilizer seemed to develop quickly during the first month and the plants attained maximum growth more rapidly. However, the plants receiving other treatment attained the same level of growth by the middle of the growing season. They all blossomed at the same time. The quantitative and qualitative measurements for potato, taken shortly following blossoming showed increased dray matter with increased amount of compost indicated that increasing the amount of MSW compost from 21.7-43.4 $\mathrm{t} \mathrm{h}^{-1}$ increased the average dry matter of the plant (above ground matter and roots) and improved the visual health of the plants. Further increase in the amount of MSW compost $\left(65.1 \mathrm{t} \mathrm{h}^{-1}\right)$ had a negative impact on the average weight of dry matter and the visual health of the plants. The dry matter and the visual health of the potatoes were significantly improved when applying the commercial fertilizer compared to those received MSW compost. However, applying 0.5 NPK + $0.5 \mathrm{MSW}_{1}$ significantly increased the dry matter and improved the visual health of the plants.

The squash had difficulty adapting to the soil receiving MSW compost. Most of the plants died and the rest did take time to develop. The plots receiving $\mathrm{NPK}$ and $0.5 \mathrm{NPK}+0.5 \mathrm{MSW}_{1}$ showed pronounced differences in terms of plant size and maturity by the middle of July. It was, also, interesting to note that weeds were significantly retarded in the plots receiving MSW. The quantitative and qualitative measurements for the squash plants taken after fruiting showed significant improvements in the dry matter and the visual health of the potatoes when applying the commercial fertilizer compared to those received MSW compost. However, applying $0.5 \mathrm{NPK}+0.5 \mathrm{MSW}_{1}$ significantly decreased the dry matter and improved the visual health of the plants. 
Plant production: The trends observed with yield and plant height of the corn plants are similar to those observed with dry matter and the visual heath of the plants. Increasing the MSW compost application from 7.5-15 $\mathrm{t} \mathrm{h}^{-1}$ increased the number of ears per plot from 12-13. This then was decreased to 11 when the MSW compost application rate was increased to $22.5 \mathrm{t} \mathrm{h}^{-1}$. The plant height did not show any significant differences due the increase in the MSW compost application rate. The height of the corn plant increased with the application of commercial fertilizer but the number of ears was low (11). The optimum treatment was that of combined commercial fertilizer and MSW application $\left(0.5 \mathrm{NPK}+0.5 \mathrm{MSW}_{1}\right)$. It produced 18 ears and the plant height reached $212 \mathrm{~cm}$.

The average number of potatoes per plot and the average volume of potato plant canopy showed similar trends to these obtain for the dry matter and visual heath ranking. The total number of potatoes increased from 48-52 when the MSW compost application rate was doubled (from 21.7-43.4 $\mathrm{t} \mathrm{h}^{-1}$ ). A further increase in the MSW compost application rate (to $65.1 \mathrm{t} \mathrm{h}^{-1}$ ) reduced the total number of potatoes significantly (to 43). Similar trends were observed for the average plant canopy volume. The application of commercial fertilizer produced greater number of potatoes with much larger sizes. The results also showed that a combination of commercial fertilizer and MSW compost $\left(0.5 \mathrm{NPK}+0.5 \mathrm{MSW}_{1}\right)$ achieved the best results, greater number of potatoes with much large size and substantially large plant canopy volume.

The average number of fruits and the average volume of squash plat canopy indicated that the squash did not seem to do well with MSW compost. Increasing the MSW compost application rate decreased the number of fruit per plot (from 10-8) and the canopy size (from $0.33-030 \mathrm{~m}^{3}$ ). The best treatment was that of commercial fertilizer application. It produced the greatest number of fruits (19) and the largest size of canopy $\left(1.11 \mathrm{~m}^{3}\right)$. Combing MSW compost and commercial fertilizer produced less yield (only 15 fruits/plot) and smaller canopy size $\left(0.69 \mathrm{~m}^{3}\right)$.

\section{CONCLUSION}

The plant yield for each crop followed the same patterns as those of the visual observations for health ranking and the dry matter. The results showed that 0.5 $\mathrm{NPK}+0.5 \mathrm{MSW}_{1}$ gave the best plant growth, health and yield for potato and corn while NPK gave the best plant growth, heath and yield for squash. The squash did not seem to respond well to MSW compost. It appears that the plants in the plots that received $\mathrm{MSW}_{2}$ were healthier than those in the plots that received $\mathrm{MSW}_{1}$ and $\mathrm{MSW}_{3}$. This may indicate that providing three times the requirement amount of nutrients (phosphorus or nitrogen) may provide higher levels of retardants and/or heavy metals than the plants can tolerate while providing only the required amount of phosphorous (or nitrogen) may not provide all the other required micro-nutrients. In light of these results, the long term effects of MSW compost on the soil structure and health (chemical and microbiological) should be evaluated. It would also be interesting to study also plant quality parameters such as taste, appearance, storability, susceptibility to bugs and disease as there are all important criteria to the consumer.

\section{REFERENCES}

APHA,, 1990. Standard Methods foe Examination of Water and Wastewater. American Public Health association, Washington, DC.

CCME., 2000. Compost Guidelines. Canadian Council of the Ministers of the Environment, Hull, Quebec.

Gomez-Brandon, M., C. Lazcano and J. Dominguez, 2008. Evaluation of stability and maturates during the composting of cattle manure, Chemosphere, 70: 436-441. DOI: 10.1016/j.chemosphere.2007.06.065

Havard, K.A. and P.R. Warman, 1993. Yield, vitamin and mineral analysis of organically and conventionally grown vegetables. AFDA Project Report TDP-060, Nova Scotia, Canada, pp: 67.

Jimenez, E.I. and V.P. Garcia, 1992. Determination of maturity indices for city refuse composts. Agric. Ecosyst. Environ., 38: 331-343, DOI: 10.1016/0167-8809(92)90154-4

Ko, H.J., K.Y. Kim, H.T. Kim and M. Umeda, 2008. Evaluation of maturity parameters and heavy metal content in composts made from animal wastes. Waste Manage., 28: 813-820. DOI: 10.1016/j.wasman.2007.05.010

Maso, M.A. and A.B. Blasi, 2008. Evaluation of composting strategy for managing wastes from a municipal market in Nicaragua. Bioresour. Technol., 99: 5120-5124. DOI: 10.1016/j.biortech.2007.09.083.

Maynard, A.A., 1993. Evaluation the suitability of MSW compost as a soil amendment in field grown tomatoes. Compost Sci. Utilizat., 1: 34-36.

Maynard, A.A., 1995. Increasing tomato yields with MSW compost. Biocycle, 36: 104-106.

Mays, D.A., 1973. Municipal Compost: Effects on crop yields and soil properties. J. Environ. Q., 29: 89-92. 
NSDOE., 1995. Solid Waste Resource Management Regulations. Nova Scotia Department of Environment. Halifax, Nova Scotia.

OMOA., 1982. Vegetables production guidelines. Ontario Ministry of Agriculture, Ottawa, Ontario.

Ozores-Hampton, M., 1994. Nutrient concentrations, growth and yield of tomato and squash in municipal solid- waste- amended soil. Hortscience, 29: 785-788.

Paion, V., 1996. Municipal tropical compost: Effects on crops and soil properties. Compost Sci. Utilizat., 49: 62-69.
Roe, N.E., 1993. Utilization of MSW Compost and other organic mulches on commercial vegetable crops. Compost Sci. Utilizat., 3: 73-84.

Statistics Canada, 2002. Canada Year Book. Statistics Canada, Ottawa, Ontario.

Wang, C.M., C.M. Change, M.E. Watson, W.A. Dick and Y. Chin et al., 2004. Maturity Indices of composted dairy and Pig manure. Soil Biol. Biochem., $\quad 36$ : 767-776. $\quad$ DOI: 10.1016/j.soilbio.2003.12.012 